\title{
Analysis of Core Technologies and Implementation Services for Smart City
}

\author{
Jae-saeng Kim ${ }^{1}$, Han-Yong Choi*2 \\ ${ }^{1}$ Computer Software, Kimpo Univ., Gimpo,Gyeonggi-do, Republic of KOREA \\ ${ }^{* 2}$ Computer Engineering, ShinhanUniv.,Dongducheon, Gyeonggi-do, Republic of KOREA \\ jskim@kimpo.ac.kr ${ }^{1}$, hychoi@shinhan.ac.kr ${ }^{2}$
}

Article History: Received: 11 January 2021; Accepted: 27 February 2021; Published online: 5 April 2021

\begin{abstract}
Smart City Platform is a software that optimally allocates resources and provides services to citizens by utilizing ICT technologies such as artificial intelligence, IoT, virtual reality, augmented reality, and 5G mobile communication to solve various urban problems occurring in the city.In order to implement the Smart City environment, basic platform technologies such as artificial intelligence, big data, network, Internet of Things(IoT) and Cloud computing are essential.In this paper, we used the big data analysis tool 'BigKinds' to lookup the topic 'Smart City Technology' and 'Smart City IoT' in news, editorials and quotations. After analyzing them, we then derived the core technologies needed in building a Smart City. Furthermore, we introduced the concept of the basic Smart City technologies and then deduced implications and drew a conclusion by analyzing both the local and foreign Smart City construction services. In addition, it compared and analyzed the core technologies for supporting services in various smart cities. The Smart City's basic technologies and service analysis can be utilized by the local government to effectively establish policies and technology strategies in the Smart City industry.
\end{abstract}

Keywords:Smart City, Platform, Smart City Service, Cloud, IoT.

\section{Introduction}

Smart City is a futuristic, eco-friendly city connected through a network where the public functions of the city are planned, designed, and built using advanced information and communication technology anytime, anywhere[1]. Currently, cities where more than $54 \%$ of the world's population lives have many social problems such as high crime rate, traffic congestion, housing problems, and environmental pollution. Local and foreign governments are competitively adopting the Smart City environment in an attempt to solve these city problems and improve the quality of life of their citizens. In order to implement the Smart City environment, basic platform technologies such as artificial intelligence, big data, network, Internet of Things(IoT) and Cloud computing are essential. The most commonly provided service to citizens is data analysis and utilization through Smart City platforms in various fields including transportation, safety, energy, environment, education, business, medical care and city administration. In this paper, the core technologies for Smart City construction were derived using the big data analysis tool 'BigKinds' [2], and we also analyzed both local and foreign Smart city construction services that are using this technology. The content of this analysis is expected to be used for local governments to effectively establish policies and technical strategies in the Smart City industry.

\section{Basic Technologies of Smart City}

\subsection{Analysis of core technologies for smart city}

In order to derive the core Smart City technologies, we used the big data analysis tool called Big-Kainz tool and searched for the keyword 'Smart City Technology' and 'Smart City IoT' in news, editorials and quotations to analyze them. When we searched for the keyword 'Smart City Technology' between the period of January 1, 1990 to June 1, 2020, we were able to find 5,314 news article results about the topic and among others, IoT, ICT, artificial intelligence, big data and autonomous driving are some of the most relative keyword. As in Figure 1, Using the same time period, we found 1,670 news article results when we searched for the topic 'Smart City IoT' and as a result of analyzing its correlation with Smart City (weighted value, keyword frequency) and Smart City components, the most relative keywords include integrated platforms, artificial intelligence, Big data, CCTV, IoT, integrated operations center, infrastructure implementation, public WiFi and real time[2].

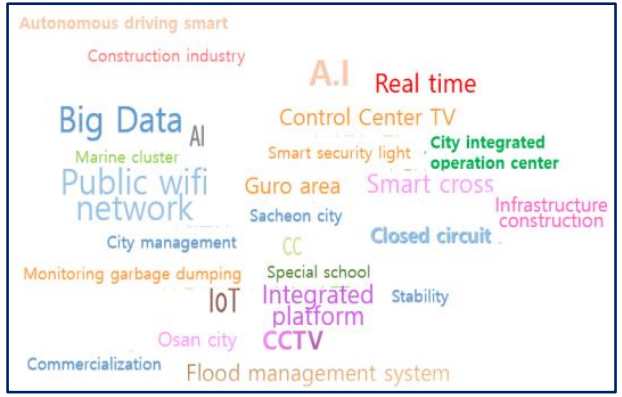

Figure 1. Analysis of related words in 'Smart City Technology' 
Thus, we selected Smart City platform, Network and Communication technology, IoT, Cloud computing, Open data and big data, and artificial intelligence technology and introduced them in the next section(2.2).

\section{Core technologies of smart city}

\subsubsection{Smart City Platform}

Smart City Platform is a software that optimally allocates resources and provides services to citizens by utilizing ICT technologies such as artificial intelligence, IoT, virtual reality, augmented reality, and 5G mobile communication to solve various urban problems occurring in the city. Although platform solutions vary depending on the development direction of global IT companies, it is usually divided into Integrated and IoT platforms. Integrated platform is a basic Smart City software currently used by 12 local governments in Korea since 2018 and is developed using advanced ICT technologies such as artificial intelligence, big data and Internet of Things for urban infrastructure and consists of city portal systems, control systems and video systems[3]. IoT platform is a system that mainly supports administrative services in cities such as safety management of the socially disadvantaged, lost child prevention, parking detection, street lamp control, pedestrian crossing control, smart maritime safety, and temperature and humidity detection. This platform is again divided into common platform and application platform. Common platform is an international standard oneM2M-based IoT platform that collects and controls information on sensors, devices and facilities in cities. The application platform supports administrator and service developer-based portal functions, web services, mobile app services and citizen participation services. However, Smart City is currently utilizing an urban data platform that combines integrated platforms, IoT platforms, and big data analysis technologies. The reason for that is the information related to services that utilizes intelligent sensing infrastructure such as location guidance, traffic light detection, temperature, temperature, humidity, urban pollution, and civil affairs handling can be collected and analyzed in real time to inform citizens.

\subsubsection{Network and communication technology}

This technology is the foundation technology that collects data by connecting infrastructure, devices, and people, and supports numerous endpoint services. Low Power Wide Area Network (LP WAN) is a long-distance communication technology that supports numerous devices that generate data. Local networking technologies such as Zigbee and WiFi, licensed cellular networking like 3/4G, and 5G technologies like LoRaWAN and 802.11 ah are characterized by unlicensed frequencies, low power and low cost, and can provide services to smart cities free of charge with relatively low capital. In 3/4G technology, the 3GPP standard has a high data transfer rate of LTE-A because it can be connected to various wireless networks simultaneously, such as CAT-1, CATM1 narrowband IoT LTE (Long-Term Evolution) [4]. In 2019, South Korea launched 5G (5th Generation) services through smartphone companies to realize the world's first smartphone-based 5G commercialization. 5G mobile communication is a key infrastructure that can support essential broadband, high data transfer rates, adaptability, energy efficiency, and real-time functions needed to implement future smart cities. In many different networking environments, Software Defined Networking (SDN) technology modify services and Network Function Virtualization (NFV) technology deals with network functions well.

\subsubsection{Internet of things}

Internet of Things refers to an intelligent infrastructure environment where information is exchanged on its own through wired and wireless network connections by attaching a sensor to everything such as smartphones and cars. Through open standard protocols (HTTP, etc.) and REST web technologies, this technology can detect, analyze and manage data generated from urban infrastructure at low cost. IoT technology can be classified into sensor technology, service interface technology, network infrastructure and wired and wireless communication technology[1]. Sensor technology is used in devices such as environmental sensor, air conditioning sensor, lighting sensor, set-top box, security sensor, window sensor, remote sensor, motion sensor, and door sensor. For example, a car can send weather or traffic information on its own to the driver's smartphone over the internet. The service interface technology is a base technology that takes care of the information generated from various devices on the IoT system and makes them available to applications. Network infrastructure, and both wired and wireless communication technologies are the infrastructure technologies that help devices connect to the Internet.

\subsubsection{Cloud computing}

Cloud computing refers to an environment where resources such as servers, storage devices, databases, and networking can be used as desired over the Internet. This is a low-cost, high-efficiency computing technology used by cities to manage and deliver services. Cloud computing is divided into three service models according to the provision of resources $[5,6]$. 
1) Iaas(Infra structure as a service): This service provides access to building block circuits that make up computers such as datacenters, virtual servers, and databases. It requires large servers, management capabilities, capital, etc., it can expand the servers in the virtual space on its own, and can also build the infrastructure needed to run the app[7,21].

2) SaaS(Software as a Service): Also called as On-demand SW, this service is commercial software that provides infrastructure and software products immediately when users pay for it $[8,20]$

3) PaaS( Platform as a Service): This service is a model that provides a platform directly from the service provider. Edge Computing is a technology that provides services by placing virtual servers in a physical location closer to users at the edge of the network to reduce processing latency. In order to collect and deliver a lot of data detected in intelligent transportation systems etc. It can operate and monitor a distributed infrastructure by utilizing the IoT infrastructure with powerful processing and gateway devices[9].

\subsubsection{Open data and big data}

In Smart City, data can be divided into open data and big data. Open data is the data that public institutions utilize and disclose to citizens. This becomes a source of big data that generates parking information, traffic conditions and environmental pollution by utilizing technologies such as the Internet of Things and Cloud Computing. Big data is generated through mobile terminals and sensors, and is effectively analyzed using the latest artificial intelligence technologies such as Hadoop Distributed File System (HDFS), Spark, Hive, and Plethora. There are various types of big data information related to smart cities, including the number of pedestrians, car traffic, water quality, energy consumption, citizen health status and activity. Private, corporate and urban officials are using this information to help decision-making or solve urban problems.

\subsubsection{Artificial intelligence technology}

Artificial intelligence technology is a technology that embodies rational, logical, and intellectual human-like abilities through computer. Machine learning allows a person to enter data learning directly or to learn specific parts, while Deep learning is an algorithm that solves important problems through artificial neural network structures that have similar functions to the human brain with data such as images, sounds, and natural languages. In smart cities, artificial intelligence technology is being used in a three-level pattern.

Level 1: Image or voice-related Internet of Things applications generated in Smart City.

Level 2: Smart city Internet of things application that accumulates transmission learning from application.

Level 3: Smart City's extensive business applications using advanced machine learning or deep learning methods.

Representative smart city services using artificial intelligence technology includes "Dasomi", a chatbot in Gimpo City that acts as a companion and guardian for seniors, "Artificial Intelligence English Teacher" at the Seoul Metropolitan Office of Education, and the "Blast furnace no. 2" that collects and analyzes data from dozens of sensors at POSCO plants.

\section{Analysis of Smart City Services in Korea and Abroad}

\subsection{Abroad}

\subsubsection{United States of America}

The USA government has selected 10 major cities, including Birmingham, Jackson and Kansas City, developing them with IT solution companies and financial companies such as Intel, AT\&T, and Cisco to solve energy, water, waste and air pollution problems.

As in Table 1, In New York, the city is operating a civil service app and NYC OpenData service in order to solve problems of aged facilities such as subways, district heating, and pipes in the city[10]. In the urban regeneration project called Neighbors Build Neighborhoods (NBN) in Rochester City, the city is divided into 10 districts. Each district is connected to the internet network in order to collect and share various city information to increase work efficiency. In Chicago's Array of Things (AoT) project, about 500 sensors installed around the city are used to collect and then analyze data such as air quality, noise, harmful substances, and human movement. The data is then released on the data portal to support citizens and policy makers with the information. Meanwhile in Boston, information on solving traffic congestion and parking problems is provided in order to reduce traffic congestion. 
Table 1. Smart City service areas of USA

\begin{tabular}{|c|c|cc|}
\hline $\begin{array}{c}\text { City } \\
\text { name }\end{array}$ & $\begin{array}{c}\text { Smart City } \\
\text { subject }\end{array}$ & \multicolumn{2}{|c|}{ Main service area } \\
\hline Chicago & $\begin{array}{c}\text { Lighting } \\
\text { System }\end{array}$ & $\begin{array}{c}\text { - Smart Streetlight Service in } \\
\text { Parks }\end{array}$ \\
\hline $\begin{array}{c}\text { Miami- } \\
\text { Dade }\end{array}$ & $\begin{array}{c}\text { Platform } \\
\text { Construction }\end{array}$ & $\begin{array}{c}\text { - Advanced V2X service } \\
\text { using taxis and autonomous } \\
\text { buses }\end{array}$ \\
\hline Montreal & $\begin{array}{c}\text { Smart } \\
\text { Parking }\end{array}$ & $\begin{array}{c}\text { - Smart Parking App Service } \\
\text { - Emergency Room Search } \\
\text { Service }\end{array}$ \\
\hline $\begin{array}{c}\text { State of } \\
\text { New York }\end{array}$ & $\begin{array}{c}\text { Intelligent } \\
\text { /Data }\end{array}$ & $\begin{array}{c}\text { - Integrated Civil Service } \\
\text { App } \\
\text { Processing } \\
\text { buildings) }\end{array}$ \\
\hline Boston & $\begin{array}{c}\text { Smart } \\
\text { Parking }\end{array}$ & $\begin{array}{c}\text { - noise, traffic, } \\
\text { resolution/parking service }\end{array}$ \\
\hline $\begin{array}{c}\text { Rocheste } \\
\text { r }\end{array}$ & $\begin{array}{c}\text { UrbanReg } \\
\text { eneration }\end{array}$ & $\begin{array}{c}\text { Traffic Intra-city information } \\
\text { sharing Service }\end{array}$ \\
\hline
\end{tabular}

\subsubsection{Australia}

Australia is expanding smart city services including commercializing wireless communication services such as infrastructure and broadband 5G in big cities with large population like Sydney and Melbourne. Melbourne is a new city with a population in their late 20 s on the average. As in Table 2, The city also has a solar trash can they call "Big Belly Bins" and a sensor-based garbage collection truck[11]. Moreover, citizens can use City Lab and an open data platform to suggest City Hall civil services. In the Hunter Innovation Project of the small provincial city of Newcastle City, smart city infrastructures such as smart parking lot and transportation, pedestrian movement, noise location, innovation hub, smart lighting, free Wi-Fi provision, and digital zone are being built. A smart crime prevention platform is also being developed using multi-sensor analysis technology.

Table 2. Smart City service areas of Australia

\begin{tabular}{|c|c|c|}
\hline $\begin{array}{l}\text { City } \\
\text { name }\end{array}$ & $\begin{array}{c}\text { Smart City } \\
\text { subject }\end{array}$ & Main service area \\
\hline $\begin{array}{l}\text { Capital } \\
\text { Territory }\end{array}$ & $\begin{array}{c}\text { Smart } \\
\text { Warden Zone }\end{array}$ & $\begin{array}{l}\text {-Energy Management } \\
\text { Service installed at } \\
\text { buildings and bus } \\
\text { intersections }\end{array}$ \\
\hline $\begin{array}{r}\text { Norther } \\
n \text { Territory }\end{array}$ & $\begin{array}{c}\text { Darwin } \\
\text { City } \\
\text { transformation }\end{array}$ & $\begin{array}{l}\text { - } \text { IoT-based } \\
\text { Service, Open Data } \\
\quad \text { (Wifi, Lighting, Parking } \\
\text { etc.) } \\
\quad \text { Business Community } \\
\text { through Open Data }\end{array}$ \\
\hline $\begin{array}{l}\text { New } \\
\text { South } \\
\text { Wales }\end{array}$ & $\begin{array}{r}\text { Newcastle' } \\
\text { s Smart Travel }\end{array}$ & $\begin{array}{l}\text { - Smart Transportation(Bus } \\
\text { Stops, Parking Lot), - } \\
\text { Energy(Solar, Electric Charging } \\
\text { Station) }\end{array}$ \\
\hline $\begin{array}{r}\text { Wester } \\
n \text { Australia }\end{array}$ & $\begin{array}{c}\text { New } \\
\text { Renewable } \\
\text { Energy/Water } \\
\text { Quality System }\end{array}$ & $\begin{array}{l}\text { - Electrical/Water Resources } \\
\text { System } \\
\text { - Blockchain-based } \\
\text { renewable energy } \\
\text { - Electric vehicles, battery } \\
\text { storage, etc. }\end{array}$ \\
\hline $\begin{array}{l}\text { Queensl } \\
\text { and }\end{array}$ & $\begin{array}{l}\text { Marine } \\
\text { Park Water } \\
\text { Quality }\end{array}$ & $\begin{array}{l}\text { - Real-time check of water } \\
\text { quality through } \\
\text { sensors in Great Barrier } \\
\text { Reef Marine Park } \\
\text { - Pollution level and water } \\
\text { quality management }\end{array}$ \\
\hline Victoria & Renev & - Real-time pollution check \\
\hline
\end{tabular}




\begin{tabular}{|l|l|l|}
\hline & $\begin{array}{c}\text { Energy/ Water } \\
\text { Quality System }\end{array}$ & $\begin{array}{c}\text { in Latrobe Valley } \\
- \text { Weather Data collection } \\
\text { and utilization }\end{array}$ \\
\hline
\end{tabular}

\subsubsection{Spain}

In Spain, 65 cities are registered as smart cities and services are divided by city into smart cities, 5G, smart farming and fishing villages, and smart tourism. As in Table 3, With the goal of being a digital city, Barcelona is focusing on public services, cooperative economy, and infrastructure. Moreover, through the mobile web platform 'Decidim Barcelona', citizens can propose public policies including urban development strategies[12,13]. The city of Santader is divided into a total of 22 districts, with each district having a number of sensors, automated devices, and CCTVs to name a few.All of them are connected to an integrated system so information such as pollution, weather, parking, traffic, garbage collection, air conditions, and seaside situation can be collected and analyzed in real time.

Table 3. Smart City service areas of Spain

\begin{tabular}{|c|c|c|}
\hline $\begin{array}{c}\text { City } \\
\text { name }\end{array}$ & $\begin{array}{c}\text { Smart City } \\
\text { subject }\end{array}$ & Main service area \\
\hline $\begin{array}{c}\text { Barcel } \\
\text { ona }\end{array}$ & $\begin{array}{c}\text { Urban } \\
\text { Regeneration Project }\end{array}$ & $\begin{array}{c}\text { - Building Old Industrial Complex as cluster of learning innovation in } \\
\text { media, energy, etc. } \\
\text { - Smart Parking, Smart Street Lamps, Smart Energy Services. - Focus on } \\
\text { public services, cooperative economy, and infrastructure }\end{array}$ \\
\hline $\begin{array}{c}\text { Santa } \\
\text { nder }\end{array}$ & $\begin{array}{c}\text { Information } \\
\text { Collection and } \\
\text { Analysis }\end{array}$ & $\begin{array}{c}\text { - Operate integrated systems of 20,000 sensors, CCTVs, etc. in the city- } \\
\text { Real-time services such as weather, parking, traffic, garbage collection, } \\
\text { pollution, seaside information, etc. }\end{array}$ \\
\hline $\begin{array}{c}\text { Madri } \\
\text { d }\end{array}$ & $\begin{array}{c}\text { Urban Service } \\
\text { Improvement }\end{array}$ & $\begin{array}{c}\text { - Real-time intra-city information collection/analysis, platform MiNT } \\
\text { operation- General city services including city beautification, lighting, road } \\
\text { pavement, etc. }\end{array}$ \\
\hline $\begin{array}{c}\text { Malag } \\
\text { a }\end{array}$ & $\begin{array}{c}\text { Trial City/ } \\
\text { Europe's Silicon } \\
\text { Valley }\end{array}$ & $\begin{array}{c}\text { - Energy services such as renewable water, bio gas energy, water usage } \\
\text { regulation- Integration of 52 district's local administrative services }\end{array}$ \\
\hline $\begin{array}{c}\text { Valen } \\
\text { cia }\end{array}$ & $\begin{array}{c}\text { Providing DB } \\
\text { Information in the } \\
\text { City }\end{array}$ & $\begin{array}{c}\text { - Digital Platform VLCi Service } \\
\text { - Real-time provision of 45 provincial services } \\
\text { - Integrate services into online form }\end{array}$ \\
\hline
\end{tabular}

\subsubsection{Japan}

More than large cities, Japan is prioritizing transforming old and shrinking provincial cities into a Smart City that is appropriate for its own characteristics. As in Table 4, The city of Kashiwanoha aims to be self-sufficient by utilizing solar and wind power to directly produce energy in order to increase energy efficiency[14,15]. The city also boasts a service of sharing various information through the shared office 'KOIL'. Desiocho City in Hokkaido offers a senior care service where the elderly can remotely communicate through video by connecting to the television. Kyotango City is developing a platform that supports medical instruments and telemedicine functions that can transmit and receive data. Hitachi City is developing a "Hitachi Bus, Rapid and Transit" system that will remake old railroads into a road dedicated for autonomous buses by 2021 . Autonomous bus roads are safe because they can be remotely monitored and operated, therefore reducing manpower costs and allowing buses to drive to mountainous areas.

Table 4. Smart City service areas of Japan

\begin{tabular}{|c|c|c|}
\hline City name & $\begin{array}{l}\text { Smart City } \\
\text { subject }\end{array}$ & \multicolumn{1}{c|}{ Main service area } \\
\hline $\begin{array}{c}\text { Chiba Prefecture } \\
\text { Kashiwanoha }\end{array}$ & $\begin{array}{c}\text { Environment, Health and } \\
\text { New Industry }\end{array}$ & $\begin{array}{l}\text { - Production of energy through solar/wind power } \\
\text { - Information sharing through 'KOIL' office } \\
\text { - Smart Health Support for Children/The Elderly }\end{array}$ \\
\hline Desiocho & $\begin{array}{c}\text { Senior Care Service } \\
\text { Telemedicine }\end{array}$ & $\begin{array}{l}\text { - Elderly Remote Assistance Service by connecting } \\
\text { to television } \\
\text { - Medical instruments for sending and receiving } \\
\text { data and platform development }\end{array}$ \\
\hline Kyotango & Methods of Payment & $\begin{array}{l}\text { - Prepaid card payment in Elves Coin area } \\
\text { - Bluetooth payment using apps }\end{array}$ \\
\hline Takamatsu City & VR Shopping Service & - Virtual shopping mall service using VR \\
\hline Hitachi City & Transportation Support & - Using railroads as road for autonomous bus \\
\hline
\end{tabular}




\begin{tabular}{|c|c|c|}
\hline & & $\begin{array}{c}- \text { Development and Operation of Hitachi Bus } \\
\text { System }\end{array}$ \\
\hline Kumamoto City & Senior Care & $\begin{array}{c}\text { - Remote identification of the elderly using sensors } \\
- \text { Senior Independence Support Service }\end{array}$ \\
\hline
\end{tabular}

\subsubsection{China}

The nationwide mobile payment market share in China is 54\%. As in Table 5, In Hangzhou, mobile payment is implemented on all taxis in the city and most supermarkets and convenience stores offer Alipay payments[16,17,18]. Citizens have access to a total of 60 kinds of services, including administrative services, medical and vehicle services, and public transportation.

Table 5. Smart City service areas of China

\begin{tabular}{|c|c|c|}
\hline City name & $\begin{array}{l}\text { Smart City } \\
\text { subject }\end{array}$ & Main service area \\
\hline Hangzhou & $\begin{array}{l}\text { 'City Brain' } \\
\text { Mobile City }\end{array}$ & $\begin{array}{l}\text { - Mobile Taxi Payment, } \\
\text { Alipay Payment } \\
\text { - Smart community } \\
\text { support for the elderly } \\
\text { - Road/Signal } \\
\text { Congestion, Traffic } \\
\text { Situation Service }\end{array}$ \\
\hline $\begin{array}{l}\text { Guangdo } \\
\text { ng Province } \\
\text { Shenzhen }\end{array}$ & $\begin{array}{l}\text { Eco-friendly } \\
\text { transportation }\end{array}$ & $\begin{array}{cr}\text {-Port City, } & \text { Transport } \\
\text { Centralization } & \\
\text { - Circulate } & \text { electric } \\
\text { vehicles, electric } & \text { taxis, } \\
\text { electric buses } & \\
\end{array}$ \\
\hline $\begin{array}{l}\text { Jiangsu } \\
\text { Province } \\
\text { Wuxi }\end{array}$ & $\begin{array}{l}\text { Sensor Net- } \\
\text { work, Next } \\
\text { Generation } \\
\text { Internet }\end{array}$ & \begin{tabular}{lr} 
- Cloud & Computing \\
Services & TD-LTE/Next \\
Generation & Internet/Wired \\
and Wireless & \\
\multicolumn{2}{c}{ - Communications and } \\
Broadcasting & Network \\
Integration- & E-commerce \\
trial city
\end{tabular} \\
\hline $\begin{array}{l}\text { Xiong'an } \\
\text { District, } \\
\text { Baoding }\end{array}$ & $\begin{array}{l}\text { Cloud-Based } \\
\text { AI Future City }\end{array}$ & $\begin{array}{l}\text {-City's Neural Network- } \\
\text { Based Self-driving Service } \\
\text { - Utilization of Artificial } \\
\text { intelligence, block chain, } \\
\text { next generation ICT, bio- } \\
\text { technology etc }\end{array}$ \\
\hline Shanghai & $\begin{array}{l}\text { Government } \\
\text { Services }\end{array}$ & \begin{tabular}{lr}
\multicolumn{1}{c}{ State } & Affairs \\
Administration & Services, \\
Cloud $\quad$ Development- \\
Shopping Brand/Smart Sales
\end{tabular} \\
\hline
\end{tabular}

The new Xiong'an District in Baoding, Hebei Province is creating a cloud-based AI city by connecting IoT technology and cloud-based infrastructure with neural networks. Shanghai is developing into a digital economic city all the while implementing the Shanghai shopping brand, integrating the Yangtze River Delta and more.

According to the analysis of foreign smart city construction services, Smart city services are greatly influenced by the infrastructure characteristics and environment of their own country. In order to improve their quality of life, advanced countries such as the U.S. and Europe are driven by their private sectors, whose focus are mostly on topics of urban regeneration and climate change. However, developing countries such as Asian countries are driven by their public sectors to strengthen their national competitiveness. These countries' main objective is to advance in responding to issues such as abrupt urban problems, and stimulating the economy. In foreign countries, the most progressive sectors are electronic administrative services and education, energy (electric vehicles etc.) transportation (parking etc.) and the health care sector.

\subsection{Korea}

Since Korea has the world's best information network infrastructure, building smart cities in more than 70 urban areas across the country is easier than in other countries. As in Table 6, To first develop solutions to solve 
each city's problems are being prioritized by local governments of cities such as Seoul, Gimpo, Dongtan, and Pangyo[19].

Table 6. Smart City service areas of Korea

\begin{tabular}{|c|c|c|}
\hline $\begin{array}{l}\text { City } \\
\text { name }\end{array}$ & $\begin{array}{l}\text { Smart City } \\
\text { subject }\end{array}$ & Main service area \\
\hline Jeonju & Fire Safety Platform & $\begin{array}{l}\text { - IoT, Blockchain Technology Service } \\
\text { - Digital twin data. Provision of Administrative Data } \\
\text { - Fire suppression and evacuation routes }\end{array}$ \\
\hline Pangyo & Smart Entertainment & $\begin{array}{l}\text { Virtual/augmented reality, music streaming } \\
\text { service-Smart parking, smart street light }\end{array}$ \\
\hline Sejong & $\begin{array}{c}\text { Self-sufficient city, } \\
\text { Autonomous Driving City }\end{array}$ & $\begin{array}{l}\text { - Autonomous detailed map, 3D spatial } \\
\text { Information system, C-ITS, etc. } \\
\text { - Smart parking, disaster prevention, storm and flood } \\
\text { monitoring - Public bicycle, energy system }\end{array}$ \\
\hline $\begin{array}{c}\text { Dongta } \\
\mathrm{n}\end{array}$ & Smart Energy & $\begin{array}{l}\text { - Zero Energy Building, Solar Power } \\
\text { - Smart Underpass, Microgrid }\end{array}$ \\
\hline $\begin{array}{l}\text { Pyeong } \\
\text { taek }\end{array}$ & $\begin{array}{c}\text { Smart trans- } \\
\text { portation/Crime services }\end{array}$ & $\begin{array}{l}\text { - Smart street lamps, Provide information of speed detection } \\
\text { - Emergency notification and crosswalk support }\end{array}$ \\
\hline Busan & Smart Water & $\begin{array}{l}\text { - Korean specialized smart water management } \\
\text { - Virtual city based on VR, AR, BIM, 3D apps }\end{array}$ \\
\hline $\begin{array}{c}\text { Gwangj } \\
\mathrm{u}\end{array}$ & $\begin{array}{l}\text { Fostering New Energy } \\
\text { Industries }\end{array}$ & $\begin{array}{l}\text { - Energy Science Park creation } \\
\text { - Power infrastructure and energy convergence system- Next } \\
\text { generation secondary battery, energy recycling, etc. }\end{array}$ \\
\hline
\end{tabular}

However, since it's difficult for old cities to support smart cities due to its characteristics, smart services suitable for the older cities are implemented instead through the Urban Renewal New Deal program of smart cities. Saha-gu district in Busan is developing convenient services including a community space that utilizes solar power (such as senior citizen center), power support and smart garbage collection services based on the Urban Regeneration New Deal project. Various projects are being implemented including the smart garbage collection management solution in Goyang City and the augmented reality park experience in Daegu. According to an analysis of Smart City constructions in Korea, the most active sectors were transportation, urban administration and energy. Smart city services are developed with the planning of specialized smart cities that aims to suit the problems and characteristics of the city. The success stories of domestic and foreign smart cities are different in a way that each country has a different looking smart city that is unique and suitable to the city according to its geographical, environmental, cultural issues and characteristics. The successful cases of smart cities domestically and abroad have been established in each country according to the geographical, environmental, cultural issues and characteristics of each city, each of which has been specialized differently to be suitable for the city.

\section{Conclusion and Implementation}

All In this study, we looked at the core technologies of smart city and analyzed the trend of smart city implementations domestically and abroad. The implications obtained through the analysis of Smart City implementation domestically and abroad are as follows. First, in order to solve the problems of urbanization, the intra-city information should be quickly analyzed in real time. Results should then be provided to the members of the community in the city such as businesses, residents and the local government to help in decision-making. Second, the introduction of the Smart City platform can significantly contribute to the safety of society by reducing disease response and social costs, lowering crime figures, and shortening average work hours to name a few. Third, from the beginning of the project, smart city construction should build a specialized system by fully utilizing the characteristics of the region. Fourth, Smart City transform cities into a two-way cooperation system in which together with the government, more citizens participate in operating the city, enhancing its efficiency and sustainability. Fifth, by actively utilizing sensor, Iot, AI and big data technologies in building smart cities, we can solve urban problems by predicting demand for transportation, disasters, diseases and crimes, while effectively reducing social and urban policy costs. Sixth, this manuscript introduces the basic concept of smart city's core technology and its construction services trends, and can be used as an example case of Smart City construction for local and foreign governments. Seventh. Practical considerations were derived through the analysis of smart city construction cases domestically and abroad. In order to provide smart city services that citizens actually want in the future, it is necessary to further analyze the research on surveys and analysis of citizens' needs. 


\section{References}

1. Wikipedia, https://en.wikipedia.org/wiki/

2. https://www.bigkinds.or.kr/

3. Kyung-Wan Guk(2018). Technology Trends of Smart City Platform, KOSEN Analysis Report.

4. Hyun-Koo Kim(2018). Smart City Technology Trend Report",https://doi.org/10.22800/kisti.kosenexpert. June.

5. Hyung-gon Kim, Yong-sung Lee(2010). Current status and future prospects of cloud computing services, KICS. Information \& communications magazine ,27(12), 31 - 34.

6. Kyoung-Seung Jang, Seung-Jung Shin, JinkwanJung(2015).“A Study on Recognization for Quality Importance of CloudServices", JIIBC, 15(2), 39-44.

7. TaeWoo Kwon, Jong-Yong Lee and Kye-Dong Jung(2019). A Study of Data Interoperability System using DBaaS for Mobility Handicapped, IJIBC, 11(1), 97-102.

8. Chigon Hwang, Hyung-Seok Kim, Jong-Yong Lee, KyedongJung(2017). A study on BSN data collection technique through mobile devices in a cloud environment, IJASC, 6(2), 82-88.

9. Sookyung Hyun, Cheryl Newton(2019). Comorbidity Analysis on ICU Big Data, IJACT, 7(2), 12 18.

10. Kyung-TakLee(2017). All regions of the US are transforming into smart cities, Digital Times.

11. Ji-SeonKang(2019). The World's Best Living Cities in Australia: The Competitiveness of Smart Cities Is Strong, kotra News.

12. Busan Ilboarticle(2015). Internet of Things and Smart City: Focusing on the Barcelona Case.

13. The Korea District Heating Corporation(2019). Future City Created by Science, Smart City.

14. Japanese Prime Minister's Palace(2017). https://www.kantei.go.jp/jp/singi/tiiki/kokusentoc/supercity/dai2/ shiryou2.pdf.

15. Reporter Hyun Min(2019). Japan, where the disappearance of local cities came first, solved by smart cities.

16. http://m.boannews.com/html/detail.html

17. http://www.zdnet.co.kr/view/?no=201711151000

18. Hyun-jin Lee, Smart City News Clipping(2020).

19. Korea Policy Briefing, "Smart City (Intelligent City)", Policy Wiki

20. Akin Arikan, C. (2019). A Comparison of Kernel Equating Methods Based on Neat Design. Eurasian Journal of Educational Research, 82, 27-44.

21. Akkaya, B. (2019). The Relationship between Primary School Teachers' Organizational Citizenship Behaviors and Counter-productive Work Behaviors. Eurasian Journal of Educational Research, 84, $1-28$. 